\title{
UPAYA PENINGKATAN HASIL BELAJAR BANGUN RUANG SISI DATAR DENGAN MENGGUNAKAN KOMBINASI PENDEKATAN PEMBELAJARAN KOOPERATIF TIPE JIGSAW DAN MEDIA BENDA ASLI
}

\author{
Erna Lukitawati \\ Guru SMP NEGERI I Turen
}

\begin{abstract}
Abstrak
Penelitianini berangkat dari latar belakang perlunya dilakukan pembaharuan dalam peningkatan kreativitas mengajar guru dalam pengelolaan proses pembelajaran matematika pada materi bangun ruang sisi datar di Sekolah Menengah Pertama sebagai respons semakin melemahnya kualitas belajar siswa. Dalam kegiatan pembelajaran, materi pelajaran tidak kontekstual, dan kinerja siswa rendah, baik pada proses maupun produk belajarnya. Sebagian besar guru masih melaksanakan pembelajaran dengan pendekatan pembelajaran tradisional.Keadaan tersebut potensial menimbulkan kejenuhan, Berdasarkan uraian permasalahan di atas, melalui penelitian ini diharapkan guru mampu memainkan peran sebagai inovator pembelajaran. Peningkatan kreativitas mengajar guru dan dukungan media pembelajaran mutlak perlu dikembangkan. Penelitian ini menggunakan pendekatan kualitatif untuk mendapatkan data dan analisisnya melalui kajian-kajian reflektif, partisipatif, dan kolaboratif. Pengembangan program didasarkan data-data dan informasi dari siswa. Penelitian ini dilakukan SMP Negeri I Turen dengan tiga siklus. Pada siklus pertama, sebagian siswa belum terbiasa dengan kondisi pembelajaran kooperatif tipe jigsaw dengan menggunakan media benda asli, sehingga dilakukan tindakan dengan memberi penjelasan kepada siswa tentang prinsip-prinsip pembelajaran kooperatif tipe jigsaw. Sedangkan hasil belajar bangun ruang sisi datar siswa menunjukkan peningkatan dari rata-rata sebesar 53 pada siklus pertama menjadi 79 pada siklus kedua dan 80 pada siklus ketiga. Ketuntasan belajar siswa juga menunjukkan peningkatan dari $43 \%$ pada siklus pertama menjadi $87 \%$ pada siklus kedua dan $90 \%$ pada siklus ketiga dari nilai kriteria ketuntasan minimal 60. Dalam hal pelaksanaan penelitian tindakan kelas, siklus pertama, kedua, dan ketiga dapat disimpulkan bahwa kombinasi pendekatan pembelajaran kooperatif tipe jigsaw dan media benda asli dapat meningkatkan hasil belajar bangun ruang sisi datar dan aktivitas siswa pada siswa SMP Negeri I Turen.
\end{abstract}

Kata Kunci: bangun ruang sisi datar, aktivitas, jigsaw, media benda asli.

\section{PENDAHULUAN}

Pembangunan nasional dibidang pendidikan adalah upaya demi mencerdaskan kehidupan bangsa, dan meningkatkan kualitas manusia Indonesia dalam mewujudkan masyarakat yang maju, adil, dan makmur. Sebagai upaya mewujudkan pembangunan dibidang pendidikan antara lain diperlukan peningkatan sumber daya manusia yang terlibat dalam proses belajar mengajar, dalam hal ini guru dan siswa. Sebagai pendidik guru harus selalu berusaha meningkatkan kemampuan dan keterampilan dalam memberikan materi dan pengelolaan belajar mengajar. Sedang siswa berusaha memahami materi dengan baik sehingga dapat menyelesaikan tugas dan dapat menerapkan dalam kehidupan sehari-hari. Matematika menurut Departemen Pendidikan dan Kebudayaan (2003:6) merupakan suatu bahan kajian yang memiliki objek abstrak dan 
dibangun melalui proses penalaran deduktif, yaitu kebenaran suatukonsep diperoleh sebagai akibat logis dari kebenaran sebelumnya sehingga keterkaitan antar konsep dalam matematika bersifat sangat kuat dan jelas. Dalam pembelajaran matematika agar mudah dimengerti oleh siswa, proses penalaran induktif dapat dilakukan pada awal pembelajaran dan kemudian dilanjutkan dengan proses penalaran deduktif untuk menguatkan pemahaman yang sudah dimiliki oleh siswa. Menurut Muhammad Sholeh (1998:34) matematika sebagai ilmu pengetahuan dasar sangat dibutuhkan untuk mempersiapkan sumber daya manusia yang handal dan mampu berkompetisi. Menurut Montimer J. Alder dan Charles Van Doren (2006:316) pada kenyataannya kondisi umum yang ditemui adalah minimnya persiapan siswa dalam menghadapi materi baru, banyak siswa yang datang kesekolah tanpa persiapan pengetahuan. Pada hasil ulangan harian ke-2, semester 2, tahun pelajaran 2014/ 2015 di SMP Negeri I Turen, yang memuat materi bangun ruang sisi datar terlihat bahwa, siswa yang mendapatkan nilai di bawah 60 sebanyak 20 orang atau sebanyak $65 \%$, belum tuntas, siswa yang mendapatkan nilai di atas atau sama dengan 60 sebanyak 12 orang atau sebanyak $35 \%$ yang tuntas. Di kelas VIII-B, SMP Negeri I Turen, Pembelajaran matematika memerlukan media yang sesuai, karena menurut Mulyasa (2005:47) suatu faktor yang menyebabkan rendahnya kualitas pembelajaran antara lain belum dimanfaatkannya sumber belajar secara maksimal, baik oleh guru maupun oleh peserta didik. Menurut Suharta (2001:1) dalam pembelajaran matematika selama ini, dunia nyata hanya dijadikan tempat mengaplikasikan konsep. Siswa mengalami kesulitan belajar matematika di kelas. Akibatnya, siswa kurang menghayati atau memahami konsep-konsep matematika, dan siswa mengalami kesulitan mengaplikasikan matematika dalam kehidupan seharihari. yang ditugaskan kepada mereka. Sebab-sebab timbulnya masalah sebagai berikut:

a. Guru masih menggunakan metode pembelajaran yang konvensional dalam pembelajaran materi bangun ruang

b. Guru belum menggunakan metode pembelajaran yang tepat untuk mengatasi rendahnya keterlibatan siswa dalam proses pembelajaran materi bangun ruang sisi datar.

c. Guru belum menggunakan metode pembelajaran yang tepat untuk mengatasi rendahnya motivasi belajar siswa terhadap materi bangun ruang.

d. Guru belum menggunakan media pembelajaran yang tepat untuk membantu siswa dalam memahami konsep-konsep yang abstrak dalam materi bangun ruang sisi datar.

Permasalahan mendasar dalam penelitian ini adalah sebagian besar siswa kelas VIIIB SMP Negeri I Turen kurang memahami konsep bangun ruang sisi datar. Bertitik tolak dari uraian di atas, maka dirumuskan masalah dalam penelitian ini sebagai berikut: "Apakah penggunaan kombinasi pendekatan pembelajaran kooperatif tipe Jigsaw dan media benda asli dapat meningkatkan hasil belajar bangun ruang sisi datar siswa kelas VIIIB SMPNI Turen?" 


\section{Tujuan Penelitian}

Untuk mengetahui apakah penggunakan kombinasi pendekatan pembelajaran kooperatif tipe Jigsaw dan media benda asli dapat meningkatkan hasil belajar bangun ruang sisi datar siswa kelas VIII-B SMP Negeri I Turen.

\section{Manfaat Penelitian}

a. Bagisiswa, penelitian ini yaitu penggunaan kombinasi pendekatan pembelajaran kooperatif tipe Jigsaw dan media benda asli, bermanfaat untuk meningkatkan keaktifan dalam proses pembelajaran, karena suasana pembelajaran menyenangkan, motivasi belajar siswa meningkat, sehingga pada akhirnya akan meningkatkan hasil belajar siswa, khususnya hasil belajar bangun ruang

b. Bagi guru, hasil penelitian ini dapat jadikan sebagai masukan untuk meningkatkan proses pembelajaran pada materi bangun ruang sisi datar siswa kelas VIII SMP Negeri I Turen, dan menambah inovasi dan kreativitas dalam kegiatan belajar mengajar.

c. Bagi sekolah, hasil penelitian ini dapat dijadikan acuan dalam membuat kebijakan tentang peningkatan kualitas pembelajaran di sekolah, melalui pelatihan bagi guru tentang metode pengajaran dan media pembelajaran untuk meningkatkan kualitas pembelajaran.

\section{METODE PENELITIAN}

Penelitian ini menggunakan penelitian tindakan kelas (classroom action research), karena penelitian tindakan kelas merupakan penelitian yang lebih sesuai dengan tugas pokok dan fungsi guru, meningkatkan kualitas pembelajaran, meningkatkan kualitas hasil belajar siswa, serta mencapai tujuan pembelajaran atau pendidikan. Penelitian ini dilaksanakan mengikuti tahap-tahap penelitian tindakan kelas (classroom action research) yang dikemukakan oleh Kemmis dan Mc Taggart, dengan komponen tindakannya adalah perencanaan (planning), tindakan (acting), pengamatan (observing), dan refleksi (reflecting).

\section{Subyek Penelitian}

Dalam penelitian ini yang menjadi subyek penelitian adalah siswa kelas VIII-B SMP Negeri I Turen, semester genap, tahun tahun pelajaran 2014/ 2015. Jumlah siswa kelas VIII-B seluruhnya ada 32 siswa, terdiri dari 20 siswa laki-laki dan 12 siswa perempuan.

\section{Prosedur Kerja Penelitian}

Tindakan yang digunakan adalah penerapan kombinasi pendekatan pembelajaran kooperatif tipe Jigsaw dan media benda asli Siklus I

\section{Rencana Tindakan (Planning)}

1. Membuat Rencana Pelaksanaan Pembelajaran

2. Menyiapkan Lembar Kerja Siswa

3. Menyiapkan Instrumen Pengumpul Data Sebelum penelitian tindakan kelas dilaksanakan peneliti menyiapkan (1) lembar pengamatan diskusi dalam pembelajaran kooperatif tipe Jigsaw; (2) lembar observasi untuk siswa; (3) lembar pengamatan proses belajar mengajar responden guru; (4) pedoman wawancara responden siswa; 
(5) pedoman wawancara responden teman sejawat guru (6) lembar evaluasi kompetensi dasar 5.1 Dalam persiapan juga akan disusun (7) daftar nama kelompok diskusi asal yang dibuat secara heterogen, dengan memperpimbangkan anak yang berkemampuan tinggi, sedang, dan rendah. Juga akan disusun (8) daftar nama kelompok ahli dalam materi kubus, balok, prisma, dan limas; (9) media benda asli bangun ruang sisi datar yang berupa kubus, balok, prisma, dan limas; (10) daftar perolehan hasil belajar bangun ruang sisi datar siswa kompetensi dasar.

\section{Prosedur Tindakan}

\section{Tahap pendahuluan}

Tahap pendahuluan guru menyampaikan tujuan pembelajaran, dan memotivasi peserta didik.

\section{Tahap inti}

a. Dari empat puluh siswa, membagi siswa dalam delapan kelompok asal yang tiap kelompoknya terdiri dari lima siswa secaraheterogen, dengan mempertimbangkan siswa yang berkemampuan tinggi, sedang, dan rendah. Kelima siswa dari kelompok asal diberi tugas masing-masing satu materi ahli, yaitu materi kubus, balok, prisma, limas persegi, dan limas persegi panjang. Kemudian masing-masing ahli membentuk lima kelompok ahli.

b. Kelima kelompok ahli masing-masing diberikan materi diskusi tentang bangun ruang sisi datar kubus, balok, prisma, limas persegi, dan limas persegi panjang. Jadi ada kelompok ahli kubus, kelompok ahli balok, kelompok ahli prisma, kelompok ahli limas persegi dan kelompok ahli limas persegi panjang.

c. Masing-masing siswa dari kelompok ahli kembali ke kelompok asalnya untuk menjelaskan kepada teman di kelompok asalnya tentang materi yang didiskusikan ketika di kelompok ahli.

d. Salah satu dari kelompok asal mempresentasikan hasil kerja dari kelom-poknya, dan ditanggapi oleh kelompok asal yang lain.

e. Penguatan dan kesimpulan secara bersama-sama.

\section{Tahap penutup}

Siswa membuat rangkuman subbab yang telah dipelajari, dan siswa diberikan pekerjaan rumah.

\section{Pelaksanaan Tindakan (Action) Pertemuan Pertama \\ Pendahuluan:}

Menyampaikan tujuan pembelajaran.

Memotivasi peserta didik

\section{Kegiatan Inti}

a. Peserta didik dibagi menjadi 5 kelompok ahli dalam bidang ku-bus, balok, prisma, limas persegi, dan limas persegi panjang kemudian diberikan stimulus berupa pemberian materi, kemudian antara peserta didik dan guru mendis-kusikan materi tersebut. Setiap kelompok ahli diberikan media benda asli sesuai dengan bidang keahliannya, untuk didiskusikan dalam kelompoknya. Guru memberikan Lembar Kerja Siswa, untuk dikerjakan dalam kelompok ahli. Peserta didik kembali dalam kelompok asalnya dan saling bertukar pikiran, dan saling menjelaskan dari apa yang di peroleh ketika berdiskusi di kelompok ahlinya. 
b. Peserta didik mengkomunikasikan secara lisan tiap kelompok mempresentasikan.

\section{Penutup}

a. Peserta didik membuat rangkuman subbab yang telah dipelajari.

b. Peserta didik diberikan PR

\section{Pengamatan (Observation)}

Pada tahap ini peneliti merekam berbagai dampak yang muncul dalam proses pelaksanaan tindakan, yaitu penerapan kombinasi pendekatan pembelajaran kooperatif tipe Jigsaw dan media benda asli. Mengukur hasil tindakan (variabel masalah). Pada tahap ini peneliti mengukur ketercapaian hasil tindakan yaitu hasil belajar bangun ruang sisi datar, Aspek hasil belajar bangun ruang sisi datar, kompetensi dasar. Mengidentifikasi sifat-sifat kubus, balok, prisma dan limas serta bagian-bagiannya, indikatornya apabila.

\section{Refleksi (Reflecting)}

Penelitian tindakan kelas ini berhasil apabila memenuhi eberapa syarat sebagai berikut: (1) Siswa aktif berpartisipasi dalam proses pembelajaran yang merlihat dari berani dan mampu menjawab pertanyaan dari guru. (2) Siswa aktif berpartisipasi dalam proses pembelajaran yang terlihat dari berani menanggapi dan mengemukakan pendapat tentang jawaban siswa yang lain kelompoknya. (3) Siswa mengalami peningkatan hasil belajar bangun ruang sisi datar, dengan kriteria ketuntasan minimal (KKM) perorangan sama dengan 60 untuk masing-masing kompetensi dasar (KD) dan secara klasikal untuk masing kompetensi dasar
(KD), hasil belajar bangun ruang sisi datar siswa mencapai lebih atau sama dengan $85 \%$ dari seluruh siswa di kelas itu mendapat nilai 60 atau lebih.. Guru dalam melaksanakan penggunaan kombinasi metode pembelajaran dan media pembelajaran sudah sesuai dengan prosedur yang telah direncanakan.

\section{HASIL DAN PEMBAHASAN}

Siklus I

Guru belum terbiasa menciptakan suasana pembelajaran yang mengarah kepada pendekatan pembelajaran kooperatif tipe Jigsaw. Hal ini diperoleh dari hasil observasi terhadap ketepatan prosedur pelaksanaan tindakan yang dilakukan guru atau peneliti dalam proses belajar mengajar mencapai $63 \%$.

Sebagian siswa belum terbiasa dengan kondisi belajar dengan menggunakan kombinasi pendekatan pembelajaran kooperatif tipe Jigsaw dan media benda asli. Mereka belum merasa senang dan antusias dalam belajar. Hal ini bisa dilihat dari hasil observasi rata-rata prosentase data proses terhadap aspek ketepatan prosedur pelaksanaan tindakan yang dilakukan guru atau peneliti, keaktifan, perhatian, partisipasi, dan presentasi siswa, dalam proses belajar mengajar mencapai $69 \%$.

Hasil belajar bangun ruang sisi datar siswa pada siklus pertama masih kurang, baru mencapai rata-rata 53 dan siswa yang ketuntasan belajar mencapai $43 \%$.

Masih ada kelompok yang belum bisa menyelesaikan tugas dengan waktu yang ditentukan.

Masih ada kelompok yang kurang mampu dalam mempresentasikan hasil 
diskusi kelompoknya. Untuk memperbaiki kelemahan dan mempertahankan keberhasilan yang telah dicapai pada siklus pertama, maka pelaksanaan pada siklus kedua dapat dibuat perencanaan sebagai: (1) Memberikan motivasi kepada kelompok agar lebih aktif lagi dalam pembelajaran; (2) Lebih intensif membimbing kelompok mengalami kesulitan; (3) Meningkatkan tindakan proses belajar mengajar yaitu: (a) aspek ketepatan prosedur pelaksanaan tindakan yang dilakukan guru atau peneliti, (b) aspek keaktifan siswa dengan cara membangun pengetahuan anak melalui pembelajaran kontekstual dengan menggunakan media benda asli, (c) aspek perhatian siswa dengan cara menghadirkan power poin untuk menunjang pembelajaran, (d) aspek presentasi siswa dengan cara memberikan kesempatan kepada masingmasing kelompok untuk maju di depan kelas dan mengungkapkan hasil diskusi kelompoknya gaya dan bahasa dari anak; (4) Memberi pengakuan atau ( reward).

\section{Siklus Kedua}

Perolehan prosentase rata-rata data proses pada siklus kedua adalah $73 \%$, berarti ada peningkatan $4 \%$ bila dibandingkan dengan siklus pertama yang hanya mencapai $69 \%$, hal ini berarti keberhasilan proses dalam siklus kedua masih tergolong cukup. Perolehan prosentase rata-rata data proses pada siklus kedua $73 \%$, sudah mencapai target minimal yang ditetapkan pada indikator keberhasilan proses sebesar $65 \%$.

Hasil observasi pada siklus kedua perolehan skor rata-rata kelompok aspek minat dan kepuasan siswa dalam mengikuti kegiatan belajar mengajar adalah $75 \%$. Hal ini aspek minat dan kepuasan siswa dalam mengikuti kegiatan belajar mengajar tergolong cukup, tetapi mendekati baik artinya siswa sudah mulai menyenangi kombinasi pendekatan pembelajaran kooperatif tipe jigsaw dan media benda asli, meskipun ada penurunan $1 \%$ jika dibandingkan dengan siklus pertama yaitu $76 \%$.

Hasil Evaluasi Siklus Kedua, Penguasaan Siswa terhadap Materi Pembelajaran Selain aspek ketepatan prosedur pelaksanaan tindakan yang dilakukan guru atau peneliti dalam proses belajar mengajar, penguasaan siswa terhadap materi pembelajaran meningkat 26\%. Dari skor ideal 100 skor perolehan rata-rata pada siklus kedua mencapai 79 atau $79 \%$ dan siswa yang mencapai ketuntasan belajar meningkat $44 \%$, dari $43 \%$ pada siklus pertama menjadi $87 \%$ pada siklus kedua.

Keberhasil pada siklus Ii adalah sebagai berikut: Aktivitas siswa dalam proses belajar mengajar sudah mengarah pada pembelajaran kooperatif tipe Jigsaw. Siswa mampu membangun kerja sama dalam kelompok untuk memahami tugas yang diberikan guru. Siswa mulai mampu berpartisipasi dalam kegiatan dan tepat waktu dalam melaksanakannya. Siswa mulai mampu mempresentasikan hasil kerja dengan baik. Hal ini dapat dilihat dari data proses hasil observasi terhadap aspek ketepatan prosedur pelaksanaan tindakan yang dilakukan guru atau peneliti, keaktifan, perhatian, dan presentasi siswa meningkat 8 poin atau $8 \%$ dari $61 \%$ pada siklus pertama menjadi $69 \%$ pada siklus kedua.

Meningkatnya aktivitas siswa dalam proses belajar mengajar didukung oleh 
meningkatnya aktivitas guru dalam mempertahankan dan meningkatkan suasana pembelajaran yang mengarah pada pembelajaran kooperatif tipe Jigsaw. Guru intensif membimbing siswa saat siswa mengalami kesulitan dalam proses belajar mengajar dapat dilihat dari hasil observasi aktivitas guru dalam proses belajar mengajar meningkat 15 poin atau $15 \%$ dari $63 \%$ pada siklus pertama menjadi $78 \%$ pada siklus kedua.

Meningkatnya aktivitas siswa dalam proses belajar mengajar didukung oleh meningkatnya ketepatan prosedur pelaksanaan tindakan yang dilakukan guru atau peneliti dalam mempertahankan dan meningkatkan suasana pembelajaran yang mengarah pada pembelajaran kooperatif tipe Jigsaw ditambah dengan penggunaan media benda asli dalam pembelajaran ternyata membuahkan hasil meningkatnya kemampuan siswa menguasai materi pembelajaran. Hal ini berdasarkan hasil belajar siswa dengan perolehan rata-rata 53 atau $53 \%$ pada siklus pertama meningkat menjadi 79 atau $79 \%$ pada siklus kedua. Jadi ada kenaikan sebesar 26 poin atau $26 \%$ dari siklus pertama ke siklus kedua. Demikian pula siswa yang mencapai ketuntasan belajar dengan perolehan $43 \%$ pada siklus ke-1 meningkat 44 poin atau $44 \%$ menjadi $87 \%$ pada siklus ke-2.

\section{Siklus Ketiga}

Hasil observasi siklus ketiga aktivitas guru dalam proses belajar mengajar mendapat rerata nilai perolehan 53 dari skor ideal 60 atau 88\%. Hal ini berarti menunjukkan adanya peningkatan sebesar 10 poin atau $10 \%$ bila dibandingkan dengan siklus kedua, dan menunjukkan adanya peningkatan sebesar 25 poin atau $25 \%$ bila dibandingkan dengan siklus pertama.

Hasil evaluasi siklus ketiga penguasan siswa terhadap materi pembelajaran memiliki rerata 80 atau $80 \%$ dari skor ideal 100. Hal ini menunjukkan penguasaan siswa terhadap materi pembelajaran tergolong baik. Pada siklus ketiga penguasaan siswa terhadap materi pembelajaran menunjukkan adanya peningkatan sebesar 1 poin atau $1 \%$ bila dibandingkan dengan siklus kedua, dan menunjukkan adanya peningkatan sebesar 27 poin atau $27 \%$ bila dibandingkan dengan siklus pertama. Demikian pula siswa yang mencapai ketuntasan belajar dengan perolehan $87 \%$ pada siklus ke-2 meningkat 3 poin atau $3 \%$ menjadi $90 \%$ pada siklus ke-3, dan menunjukkan adanya peningkatan sebesar 47 poin atau $47 \%$ bila dibandingkan dengan siklus pertama.Hal ini berarti menunjukkan adanya peningkatan yang sangat signifikan.

Adapun keberhasilan yang diperoleh selama siklus ketiga ini adalah sebagai berikut: Aktivitas siswa dalam proses belajar mengajar sudah mengarah pada pembelajaran kooperatif tipe Jigsaw secara lebih baik. Siswa mampu membangun kerjasama dalam kelompok untuk memahami tugas yang diberikan guru. Siswa mulai mampu berpartisipasi dalam kegiatan dan tepat waktu dalam melaksanakannya. Siswa mulai mampu mempresentasikan hasil kerja. Hal ini dapat dilihat dari data hasil observasi terhadap aktivitas siswa pada aspek minat, perhatian, partisipasi, dan presentasi meningkat 4 poin atau $4 \%$ dari $68 \%$ pada siklus kedua menjadi $72 \%$ pada siklus ketiga.

Meningkatnya aktivitas siswa dalam 
proses belajar mengajar didukung oleh meningkatnya aktivitas guru dalam mempertahankan dan meningkatkan suasana pembelajaran yang mengarah pada pembelajaran kooperatif tipe Jigsaw dan penggunaan media benda asli. Guru intensif membimbing siswa, terutama saat siswa mengalami kesulitan dalam proses belajar mengajar dapat dilihat dari hasil observasi aktivitas guru dalam proses belajar mengajar meningkat sebesar 10 poin atau $10 \%$ dari $78 \%$ pada siklus kedua menjadi $88 \%$ pada siklus ketiga.

Meningkatnya kemampuan siswa menguasai materi pembelajaran yang ditandai dengan meningkatnya hasil belajar bangun ruang sisi datar siswa sebesar 1 poin atau $1 \%$ dari hasil rerata 79 atau $79 \%$ pada siklus kedua menjadi 80 atau $80 \%$ pada siklus ketiga dan siswa yang mencapai ketuntasan belajar dengan perolehan $87 \%$ pada siklus ke-2 meningkat 3 poin atau $3 \%$ menjadi $90 \%$ pada siklus ke-3.

\section{KESIMPULAN DAN SARAN}

Berdasarkan hasil penelitian tindakan kelas dapat disimpulkan sebagai berikut:

1. Penerapan kombinasi pendekatan pembelajaran kooperatif tipe Jigsaw dan media benda asli dapat meningkatkan aktivitas proses belajar mengajar.

2. Dari hasil observasi memperlihatkan bahwa terjadi peningkatan keaktifan siswa yang pada siklus ke-1 hanya ratarata $58 \%$ menjadi $61 \%$ pada siklus ke2 dan $68 \%$ pada siklus ke-3.

3. Dari hasil observasi memperlihatkan bahwa terjadi peningkatan aktivitas siswa dalam hal ini rata-rata untuk aspek minat, perhatian, partisipasi dan presentasi yang pada siklus ke-1 hanya rata-rata $61 \%$ menjadi $68 \%$ pada siklus ke-2 dan $72 \%$ pada siklus ke-3

4. Penguasaan siswa terhadap materi pembelajaran dalam hal ini bangun ruang sisi datar menunjukkan peningkatan. Hal ini dapat ditunjukkan dengan rata- rata hasil belajar pada siklus ke-1 rata-ratanya 53 atau $53 \%$ menjadi 79 atau $79 \%$ pada siklus ke-2 dan 80 atau $80 \%$ pada siklus ke-3.

5. Kombinasi pendekatan pembelajaran kooperatif tipe Jigsaw dan media benda asli relevan dengan pembelajaran kontekstual.

6. Melalui kombinasi pendekatan pembelajaran kooperatif tipe Jigsaw dan media benda asli, siswa membangun sendiri pengetahuan, menemukan langkah-langkah dalam mencari penyelesaian dari suatu materi yang harus dikuasai oleh siswa, baik secara individu.

Telah terbuktinya kombinasi pendekatan pembelajaran kooperatif tipe Jigsaw dan media benda asli dapat meningkatkan keaktifan maupun aktivitas siswa dan hasil belajar siswa dalam pembelajaran bangun ruang sisi datar, maka kami sarankan hal-hal sebagai berikut:

1. Dalam kegiatan belajar mengajar guru diharapkan menjadikan kombinasi pendekatan pembelajaran kooperatif tipe Jigsaw dan media benda asli sebagai suatu alternatif untuk meningkatkan keaktifan maupun aktivitas siswa dan hasil belajar siswa dalam pembelajaran bangun ruang sisi datar. 
2. Karena kegiatan ini sangat bermanfaat khususnya bagi guru dan siswa, maka diharapkan kegiatan ini dapat dilakukan secara berkesinambungan dalam pelajaran matematika maupun pelajaran lain.

\section{DAFTAR PUSTAKA}

Arikunto, Suharsimi. 2005. Dasar-Dasar Evaluasi Pendidikan.jakarta: Bumi Aksara. Arsyad, Azhar. 2008.Media pembelajaran. Jakarta: Raja Grafindo Persada.

Pudijastuti, Widowati. 2001. Strategi Pembelajaran Dalam Pelatihan. Surabaya:Universitas Negeri Surabaya

Departemen Pendidikan Nasional. 2003. Standar Kompetensi Mata Pelajaran Matematika SMP \& MTs Jakarta: Pusat Kurikulum, Balitbang Depdiknas. Departemen Pendidikan Nasional. 2004. Kalender Pendidikan Nasional.

Dick, W \& Carey, L. 1985. The Sistematic Design of Instruction. Illionis, $\mathrm{CH}$ : Scott, Foreman \& Company.

Dinas Pendidikan Kab.Sidoarjo. 2006. Materi Pengembangan Profesi Guru Tahun 2006. Sidoarjo: Dinas Pendidikan Kabupaten Sidoarjo

Djamarah, Syaiful Bahri. 2000. Guru dan Anak Didik dalam Interaksi Edukatif Jakarta. Bumi Aksara. 